\title{
RESPONSE OF FLAME SEEDLESS GRAPEVINES TO FOLIAR APPLICATION OF NANO FERTILIZERS
}

\author{
Abd El- Hameed M.M. Wassel*; Moumen M.M. El-Wasfy** and \\ Moustafa M.A. Mohamed* \\ *Hort. Dept., Fac. of Agric., Minia University, Egypt. \\ * Hort. Dept., Qena Fac. of Agric., New Valley University, Egypt
}

\begin{abstract}
This study was conducted through 2015 and 2016 seasons on Flame Seedless grapevines grown in a private vineyard located at ElTawfekya village - Samalout district, Minia Governorate to investigate the effects of Six Nano fertilizers (Amino-minerals; Orgland Active-Fe, Boron-10, Amino-Zn and Super-Fe each at 0.1 to $0.2 \%$ ) on vegetative growth, vine yield, berry coloration and fruit quality.

Treated vines with 0.1 or $0.2 \%$ concentration of nanofertilizers were very effective in enhancing growth aspects, vine nutritional status and berry setting, yield, colouration and quality compared to the control treatment. The promotion was related to the application of Amino minerals, Orgland, active -Fe, Boron-10, Amino-Zn, and Super-Fe, in descending order.

Conclusively, treating flame seedless grapevines three times with amino minerals nano fertilizer at $0.1 \%$ is the best treatment yield, improved berries colouration and gave high fruit quality.
\end{abstract}

Keywords: Flame Seedless, Nano fertilizers, yield, berries quality.

\section{INTRODUCTION}

Nanotechnology is a promising field of interdisciplinary research. It opens up a wide array of opportunities in various fields like medicine, pharmaceuticals, electronics and agriculture. The potential uses and benefits of nanotechnology are enormous. The current global population is nearly 7 billion with $50 \%$ living in Asia (FAO, 2015). A large proportion of those living in developing countries face daily food shortages as a result of environmental impacts or political instability, while in the developed world there is surplus of food. For developing countries, the drive is to develop drought and pest resistant crops, which also maximize yield. The potential of nanotechnology to revolutionize the health care, textile, 
materials, information and communication technology, and energy sectors has been well publicized (FAO, 2015). The application of nanotechnology to agriculture and food industries is also getting attention nowadays. Investments in agriculture and food nanotechnologies carry increasing weight because their potential benefits range from improved food quality and safety to reduced agricultural inputs and improved processing and nutrition (Lion et al., 2006 and Rao et al., 2012). While most investment is made primarily in developed countries, research advancements provide glimpses of potential applications in agricultural, food, and water safety that could have significant impacts on rural populations in developing countries (FAO, 2015). This study is concentrated on modern strategies and potential of Nano-materials in sustainable agriculture management as modern approaches of nanotechnology. (Sultan et al., 2009; Prasad et al., 2014 and Mukhopudhyay, 2014 and Mahjunatha et al., 2016).

Previous studies showed that using Nano fertilizers was beneficial in enhancing growth and fruiting of horticultural crops (Ajirlao et al., 2014; Ekinci et al., 2014; Sabir, et al., 2014; Refaai, 2014 and Roshdy and Refaai, 2016).

Therefore, the present study aimed to throw some lights on the effect of some nutrients applied via Nano technology on growth characteristics and vine nutritional status, percentage of berry setting, yield, as well as physical and chemical properties of Flame Seedless grapes. Also, the effect of these substances on solving the problems of inferior quality and uneven colouration of berries which reflected in facilitating the possibility of marketing such grapevine cv. to local and foreign markets also concerned.

\section{MATERIALS AND METHODS}

This study was carried out during two successive seasons of 2015 and 2016 on thirty - nine Flame Seedless grapevines, 8- year old grown in a private vineyard located at El- Tawfekya village - Samalout district, Minia Governorate, Egypt.

The soil texture was clay (Table 1) and well drained and water table is not less than two meters deep. Vines were planted at $2 \mathrm{~m}$. in-row vines $\mathrm{x} 3 \mathrm{~m}$. in between rows in both seasons. The vines were chosen as uniform in vigour as possible, were pruned during the first week of January. Spur pruning system in gable shape supporting and were adjusted to 72 eyes (on the basis of 15 fruiting spurs $\mathrm{x}$ four eyes plus six replacement spurs $x$ two eyes). Surface irrigation system was applied 
Table (1): Analysis of the tested soil

\begin{tabular}{|l|c|}
\hline Constituents & Values \\
\hline \hline Sand $\%$ & 11.9 \\
\hline Silt \% & 10.1 \\
\hline Clay \% & 78.0 \\
\hline Texture \% & Clay \\
\hline pH $(1: 2.5$ extract) ppm & 7.5 \\
\hline E.C. (1: 2.5 extract) ppm & 250 \\
\hline O.M. \% & 1.8 \\
\hline CaCO3 \% & 2.25 \\
\hline Total N \% & 0.09 \\
\hline Available P ( Olsen method, ppm) & 4.9 \\
\hline Available K (ammonium acetate, ppm) & 488.5 \\
\hline EDTA extractable micronutrients (ppm) & \\
\hline Fe ppm & 3.3 \\
\hline Mn ppm & 2.9 \\
\hline Zn ppm & 4.0 \\
\hline Cu ppm & 0.4 \\
\hline
\end{tabular}

using Nile water. All the vines (39 vines) received the usual horticultural practices which are common used in the vineyard Except those dealing with the present treatments (application of Nano fertilizers).

This experiment included the following treatments applied various nutrients via sparing Nano technology.

1- Control (vines sprayed with tap water).

2- Orgland Nano fertilizer at $0.1 \%$.

3- Orgland Nano fertilizer at $0.2 \%$.

4- Active-Fe Nano fertilizer at $0.1 \%$.

5- Active-Fe Nano fertilizer at $0.2 \%$.

6- Amino - Zn Nano fertilizer at $0.1 \%$.

7- Amino - Zn Nano fertilizer at $0.2 \%$. 
8- Boron - 10 Nano fertilizer at $0.1 \%$.

9- Boron - 10 Nano fertilizer at $0.2 \%$.

10- Amino-minerals Nano fertilizer at $0.1 \%$.

11- Amino-minerals Nano fertilizer at $0.2 \%$.

12- Super - Fe Nano fertilizer at $0.1 \%$.

13- Super - Fe Nano fertilizer at $0.2 \%$.

Therefore, the study included thirteen treatments. Nano technology fertilizers namely Orgland ( $4 \% \mathrm{Fe}, 2 \% \mathrm{Mn}, 2 \% \mathrm{Zn}, 0.2 \% \mathrm{~B}$ and $0.1 \% \mathrm{Mg}$ ), Active - Fe (10 amino acids , 2\% Algae extract , 1\% vitamins and 6\% Fe), amino - Zn (10\% Amino acids, 1\% vitamins and 6\% Zn), Boron $-10(10 \%$ Amino acids, $1 \%$ vitamins , $10 \% \mathrm{~B}$ and $0.05 \% \mathrm{Mg}$ ), Amino-minerals (5\% Amino acids, $5 \%$ algae extract, $1 \%$ vitamins $8 \% \mathrm{~N}, 5 \% \mathrm{P}, 3 \% \mathrm{~K}$ and $10 \%$ micro nutrients and Super $-\mathrm{Fe}(6 \% \mathrm{Fe})$ were sprayed three times the first, when the of main shoot reached at least $30 \mathrm{~cm}$ in length (mid/ of March) the second just after berry setting $\left(3^{\text {rd }}\right.$ week of April) and the thread at three weeks later ( $2^{\text {nd }}$ of May) till runoff $(1-2 \mathrm{~L}$ vine solution according to date of spraying. Triton B as wetting agent was added at $0.05 \%$ to all treatments before spray, Control vines were sprayed with tap water containing. Triton $\mathrm{B}$ as a wetting agent was added at $0.05 \%$.

The present experiment was set up in a randomized complete block design (RCBD) with three replicates each with one grapevines. During both seasons, the following measurements were recorded:

1- Main shoot length $(\mathrm{cm})$ and leaf area $\mathrm{cm}^{2}$ according to Ahmed and Morsy, 1999) were measured.

2- Leaf chemical components namely chlorophylls a \& b, total chlorophylls and total carotenoids (mg/ 1.0 g F.W.) according to Von -Wettstein, $1957 \mathrm{~N}, \mathrm{P}, \mathrm{K}, \mathrm{Mg}$, (as \%) Zn, Fe, Mn and $\mathrm{Cu}$ (as ppm) according to Chapman and Pratt, 1965; Summer, 1985 and Wilde et al., 1985 were measured.

3- Percentage of berry setting, vine yield, number of clusters /or as weight were measured, length and shoulder of cluster $(\mathrm{cm})$ were measured.

4- Percentage of berries coloration.

5- Berry weight and dimensions (longitudinal and equatorial) T.S.S.\%, total acidity $\%$ as g tartaric acid/ $100 \mathrm{ml}$ juice (A.O.A.C., 2000), T.S.S./acid and total anthocyanin (Fulcki and Francis, 1968 and reducing sugars \%. (A.O.A.C. 2000)

Statistical analysis of data was done using new L.S.D. at 5\% (Mead et al., 1993). 


\section{RESULTS}

\section{1-Main shoot length and leaf area}

It is clear from the obtained data in Table (2) that varying nanofertilizers had significant effect on the main shoot length and leaf area. Spraying the six nano- fertilizers namely Amino-minerals; Orgland ActiveFe, Boron-10, Amino-Zn and Super $-\mathrm{Fe}$ each at 0.1 or $0.2 \%$ were significantly increased the main shoot length and leaf area of Flame seedless grapevines compared to the control treatment. There was an insignificant effect on such two vegetative characteristics between the two concentration of nano - fertilizer in both seasons. Application of Super Fe-, amino $-\mathrm{Zn}$ Boron -10 , active $-\mathrm{Fe}$, Orgland and Amino- minerals, in ascending order was very significantly effective in enhancing shoot length and leaf area. The maximum values of leaf area $\left(141.0 \& 139.7 \mathrm{~cm}^{2}\right)$ and shoot length $(137.0 \& 138.0 \mathrm{~cm})$ were recorded on the vines that sprayed three times with Amino-minerals nano fertilizer at 0.2\% during 2015 and 2016 seasons, respectively. Untreated vines produced the minimum values. Using super $\mathrm{Fe}$ at 0.1 to $0.2 \%$ gave the least values when compared with other nano- fertilizers. These results were true during both seasons.

\section{2-Leaf chemical composition}

It is evident from the obtained data in Tables $(2,3$ and 4$)$ that treating Flame seedless grapevines three times with any one of the six nano fertilizers (Orgland, Active - Fe, Amino - Zn, Boron- 10, Amino-minerals or Super $-\mathrm{Fe}$ ) was significantly stimulated chlorophyll a, chlorophyll b , total chlorophylls, total carotenoids, $\mathrm{N}, \mathrm{P}, \mathrm{K}, \mathrm{Mg}, \mathrm{Zn}, \mathrm{Fe}, \mathrm{Mn}$ and $\mathrm{Cu}$ relative to the check treatment. Significant differences on each chemical component were observed among all nano fertilizers. Increasing concentrations of each nano fertilizer from 0.1 to $0.2 \%$ had no significant effect on each chemical constituent. The chemical components highest values of these were observed on the vines that received Super - iron, Amino -Zn, Boron-10, Active- iron, Orgland and Amino- minerals, in ascending order. The highest values of chlorophyll a $(6.5 \& 6.2 \mathrm{mg} / 1.0 \mathrm{~g}$ F.W.), b $(2.2 \& 2.3 \mathrm{mg} / 1.0 \mathrm{~g}$ F.W. $)$, total chlorophylls $(8.7 \& 8.5 \mathrm{mg} / 1.0 \mathrm{~g}$ F.W.), total carotenoids (1.9 \& $1.7 \mathrm{mg} / 1.0$ g F.W.), N (1.75 \& $1.23 \%), \mathrm{Mg}$ (0.68 \& 0.66\%), Mn (64.5 \& 63.8 ppm), Zn (69 \& 69 ppm), and Fe (71.5 \& $72.0 \mathrm{ppm}$ ) were recorded on the vines that received amino -minerals nano fertilizer at $0.2 \%$ during both seasons, respectively. The untreated vines produced the minimum values. Leaf content of $\mathrm{Cu}$ was significantly 
unaffected with varying nano fertilizers. Similar trend was noticed during both seasons.

\section{3- Percentage of berry setting, yield and cluster aspects}

It is clear from the obtained data in Table (5) that treating Flame seedless grapevines with any one of the six nano- fertilizers at 0.1 or $0.2 \%$ was significantly improved the percentage of berry setting, yield, number of cluster, per vine as well as cluster weight and dimensions compared to the check treatment. Significant differences on each parameter was observed among all nano fertilizers. Increasing concentrations of each nano fertilizer from 0.1 to $0.2 \%$ had no significant effect on these aspects. In this respect the best nano- fertilizers are Amino-minerals, Orgland Active- Fe, Boron10, Amino-Zn and Super $-\mathrm{Fe}$, in descending order. Economical point of view from three sprays of amino mineral at $0.1 \%$ was responsible which produced the maximum berry setting $(15.0 \& 15.9 \%)$ number of clusters $(24.0 \& 34.0)$, yield $(8.8 \& 12.6 \mathrm{~kg})$, cluster weight $(365.5 \& 371.0 \mathrm{~g})$, length $(23.9 \& 24.5 \mathrm{~cm})$ and shoulder $(15.0 \& 15.5 \mathrm{~cm})$ during both seasons, respectively. The untreated vines produced the lowest values of berry setting $(9.1 \& 10.0 \%)$ and yield $(6.1 \& 6.5 \mathrm{~kg})$ in the first and second seasons, respectively. The percentage of increment on the yield due to application of amino - minerals above the check treatment reached 44.3 and $93.8 \%$ during both seasons, respectively. Number of clusters per vine the first season of study was significantly unaffected by the six investigated nano fertilizers.

\section{4-Percentage of berries colouration}

It is noticed from the obtained data in Table (6) that the percentage of berries colouration was significantly affected by varying nano fertilizer application. It was significantly improved with using any one of the six nano fertilizers (Amino-minerals; Orgland Active- Fe, Boron-10, Amino$\mathrm{Zn}$ and Super $-\mathrm{Fe}$ ) each at 0.1 to $0.2 \%$ over the control treatment. The best nano fertilizers in enhancing berries colouration were super - Fe, Amino $\mathrm{Zn}$, Boron- 10 Active- Fe, Orgland and Amino minerals, in ascending order. Increasing concentrations of these nano fertilizers from 0.1 to $0.2 \%$ had meaningless promotion on such parameters. The highest values of berries colourations $(77.9 \& 79.0 \%)$ was recorded on the vines that received Amino minerals, nano fertilizer at $0.1 \%$ during both seasons. No significant promotion on berries colouration was occurred among both concentrations). Percentage of berries colouration reached $60.0 \& 60.9 \%$ in 
the untreated vines during both seasons, respectively. Similar trend was noticed during both seasons.

\section{5- Physical and chemical characteristics of the berries}

It is reveal from the obtained data in Tables $(6 \& 7)$ that using any one of the six nano fertilizers (Amino-minerals; Orgland Active- Fe, Boron10 , Amino-Zn and Super $-\mathrm{Fe}$ ) each at 0.1 to $0.2 \%$ had significant promotion on the quality of the berries in terms of increasing berry weight and dimensions (Longitudinal and equatorial), TSS, TSS / acid, reducing sugars $\%$ and total anthocyanins and decreasing total acidity relative to the control treatment. The promotion was significantly associated with using Super- Fe, Amino - Zn, Boron- 10, Active- Fe, Orgland and Aminominerals, in ascending order. No significant promotion on quality of the berries was observed among the higher two investigated concentrations. Therefore, using $0.1 \%$ for each nano- fertilizer was recommended for producing good results from economical point of view. Treating Flame seedless grapevines three times with Amino minerals at $0.1 \%$ gave the best results with regard to quality of the berries. Unfavourable effects on quality of the berries were attributed to the neglection of nano fertilizers applications. These results were true during both seasons.

\section{DISCUSSION}

Nanotechnology has provided the feasibility of exploiting nanooscale or nanostructred materials as fertilizers carries or controlled - release vectors for building of so- called smart fertilizer as new facilities to enhance nutrient use efficiency (Al-Amin- Sadek and Jayasuriya,2007).

Encapsulation of fertilizers within a nanoparticle is one of these new facilities which are done in three ways a) the nutrient can be encapsulated inside nanoporous materials, b) coated with thin polymer film, or c) delivered as particle or emulsions of nanoscales dimensions (Rai et al., 2012). In addition, nanofertilizers will combine nanodevices in order to synchronize the release of Fertilizer-N and -P with their uptake by crops, so preventing undesirable nutrient losses to soil, water and air via direct internalization by crops, and avoiding the interaction of nutrients with soil, microorganisms, water, and air (Derosa et al., 2010).

Coating and binding of nano and subnano-composites are able to regulate the release of nutrients from the fertilizer capsule (Liu et al., 2006). In this regard, Jinghua (2004) showed that application of a nano-composite consists of $\mathrm{N}, \mathrm{P}, \mathrm{K}$, micronutrients, mannose and amino acids enhance the 
uptake and use of nutrients by grain crops. Moreover, nanotechnology could supply tools and mechanisms to synchronize the nitrogen release from fertilizers with crop requirements. This will be accomplished only when they can be directly internalized by the plants. Zinc-aluminiumlayered doublehydroxide nanocomposites have been employed for the controlled release of chemical compounds which act as plant growth regulators. Studies has shown that fertilizer incorporation into cochleate nanotubes (rolled-up lipid bilayer sheets), had improved crop yield (Derosa et al., 2010).

More recent strategies have focused on technologies to provide nanofertilizer delivery systems which react to environmental changes. The final goal is production of nanofertilizers that will release their shipment in a cardrailled manner (slowly or quickly) in reaction to different signals such heat, moisture and etc.

Since fertilizers, particularly synthetic fertilizers, have a major potential to pollute soil, water and air-, in recent years, many efforts were done to minimize these problems by agricultural practices and the design of the new improved fertilizers. The appearances of nanotechnology open up potential novel applications in different fields of agriculture and biotechnology. Nanostructured formulation through mechanisms such as targeted delivery or slow/controlled release mechanisms, conditional release, could release their active ingredients in responding to environmental triggers and biological demands more precisely. There is the possibility of using these mechanisms to design and construction of nanofertilizers. The use of these nanofertilizers causes an increase in their efficiency, reduces soil toxicity, minimizes the potential negative effects associated with over dosage and reduces the frequency of the application. Nanofertilizers mainly delays the release of the nutrients and extends the fertilizer effect period. Obviously, there is an opportunity for nanotechnology to have a significant influence on energy, the economy and the environment, by improving fertilizers. Hence, nanotechnology has a high potential for achieving sustainable agriculture, especially in developing countries.

The promoting effect of nano fertilizer on growth, nutritional status, yield and quality of Flame seedless grapevines was emphasized by the results of Refaai (2014); Sabir et al., (2014) and Roshdy and Refaai (2016).

Conclusively, treating flame seedless grapevines three times with amino minerals nano fertilizer at $0.1 \%$ is the best treatment yield, improved berries colouration and gave high fruit quality. 


\section{REFERENCES}

A.O.A.C. (2000): Official Methods of Analysis . 12th Ed., Benjamin Franklin Station, Washington D.C., U.S.A.pp.490-510.

Ahmed, F.F. and Morsy, M.H. (1999): A new method for measuring leaf area in different fruit species. Minia J. of Agric. Res. \& Develop., (19): 97-105.

Ajirlao, A.R.; Shaaban, M. and Motlegh, Z.R. (2014): Effect of K nano fertilizer and $\mathrm{N}$ biofertilizer on yield and yield components of tomato. Inter. J. of Advanced Biol. And Biomedical Res., 3(1): 135-173.

Al-Amin Sadek, M.D. and Jayasuriya, H.P. (2007): Nanotechnology prospects in agricultural context: An overview. In Processing of the International Agricultural Engineering Conference, 3-6 December 2007, Banghok, p. 548.

Chapman, H.D. and Pratt, P.P. (1965): Method of Analysis for soils, Plants and water. Univ. of California Division of Agric., Sci., 172173.

Derosa, M.R.; Monreal, C.; Schnitzar, M.; Walsh, R. and Sultan, Y. (2010): Nanotechnology in fertilizers. Nat. Nanotechnol. J. 5, 91

Ekinci, M.; Dursun, A. Yildrim, E. and Parlakova, F. (2014): Effects of nano technology liquid fertilizers on the plant growth and yield of cucumber (Cucumis sativus, L.). Acta Sci. Pol., Hortoran, Ciutlus, 13(3): 135-141.

Food and Agriculture Organization (F.A.O.) (2015): Quarterly Bulletin of Statistics. No. (112): 31 Year Book Annuario Production, 50, 154155.

Fulcki, T. and Francis, F.J. (1968): Quantitative methods for anthocyanins 1- Extraction and determination for total anthocyanins in berries. J. Food Sci., 33: 72-77.

Jinghua, G. (2004): synchrotron radiation, soft x- ray, spectroscopy and anno materials. J. Nano techno., $1: 193-225$.

Liu, X.; Feng, Z.; Zhang, J., Xiao, Q, and Wang, Y. (2006): Preparation and testing of cementing nano subnano composites of slower controlled release of fertilizers. Sci. Agr. Sin. Sin, J., 39: 1598- 1604.

Mahjunatha, S.B.; Biradar, D.P. and Aladakatti, Y.K. (2016): Nanotechnology and its applications in agriculture. A review. J. Farm. Sci., 29 (1): 1-13.

Mead, R.; Currnow, R. N. and Harted, A. M. (1993): Statistical Methods in Agricultural and Experimental Biology. $2^{\text {nd }}$ Ed. Chapman and Hall, London pp. 10- 44. 
Mukhopudhyay, S.S. (2014): Nanotechnology in agriculture prospects and constraints nanotechnology. Sci. and Application., 7: 63-71.

Prasad, R.; Kumar, V. and Prasad, K.S. (2014): Nanotechnology in sustainable agriculture, present concerns and future aspects. African J. f Biotechnology, 13 (6): 705-713.

Rai, V. Acharya, S. and Dey, N. (2012): Implications of nanobiosensors in agriculture. J. of Biomaterials and nanobiotechnology , 3: 315-324.

Refaai, M.M. (2014): Response of Zaghloul date palms grown under Minia region conditions to spraying wheat seed sprout extract and nano boron. Stem Cell , 5(4): 22-28.

Roshdy, Kh. A. and Refaai, M.M. (2016): Effect of nanotechnology fertilization on growth and fruiting of Zaghloul date palms. J. Plant Production, Mansoura Univ., 7(1): 93-98.

Sabir, A.; Yazar, K. Sabir, F.; Kara Z. Yazsci, M.A. and GoKsu, N. (2014). Vine growth, yield, berry quality attributes and leaf nutrient content of grapevines as influenced by seaweed extract (Ascophyllum nodosum) and nanosize fertilizer pulverizations. Scientia Hort., 175: $1-8$.

Sultan, Y.; Walsh, Monreal, C.M. and De Rosa, M.C. (2009): Preparation of functional Aptamer films using Layer- by- self assembly. Biomacromolecules K., 10:1149-1154.

Summer, M.E. (1985): Diagnosis and recommendation integrated system (DRIS) as a guide to orchard fertilization. Hort. Abst., 55 (88): 7502.

Von- Wettstein, D. V. (1957): Chlroophyll- Lethale under submikroshopische formilkechrel der plastiden celi, prp. Trop. Res. Amer. Soc. Hort. Sci. , 20 pp. $427-433$.

Wilde, S. A.; Corey, R. B.; Lyer, I. G. and Voigt, G. K. (1985): Soil and Plant Analysis for Tree Culture. $3^{\text {rd }}$ Oxford 8IBM publishing Co., New Delhi, pp. 1-218. 
استجابة كرمات العنب الفليم سيدليس لرش بعض الأسمدة من خلال نظام

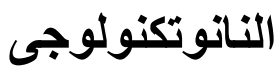

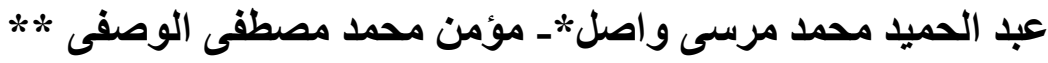

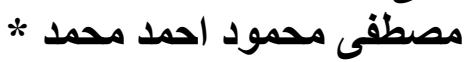

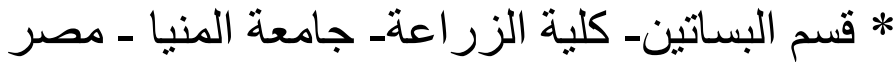

** قسم البساتين - كلية زر اعة قنا- جامعة جنوب الوعة الوادى - مصر.

تم اختبار تاثير ستة أسمدة مستخدمة من خلال نظام النانوتكنولوجى و هى

Amino-minerals; Orgland Active- Fe , Boron-10 , Amino-Zn ) (and Super -Fe

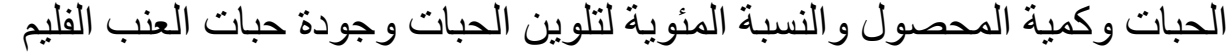
سيدليس سنة 2015 و 2016 فى مزر عة خاصة فى التوفيقيه - سمالوط ـ محافظة النية

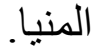

أدت معاملة الكرمات بأى سماد من الاسمدة المستخدمة من خلال نظام

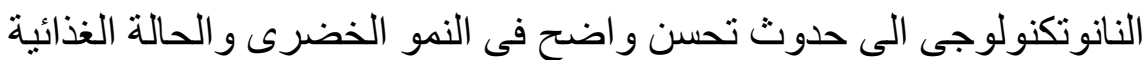

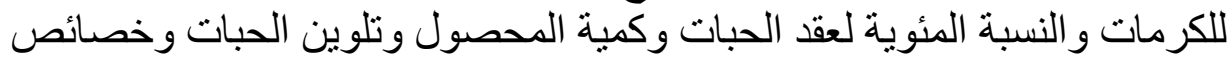

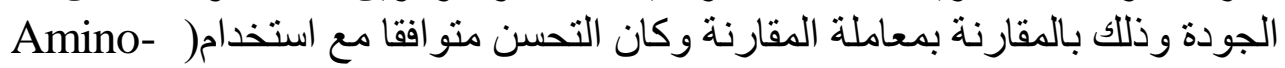
minerals; Orgland Active- Fe , Boron-10 , Amino-Zn and Super

(-Fe

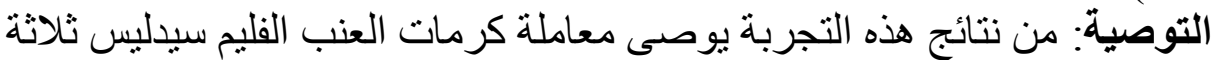

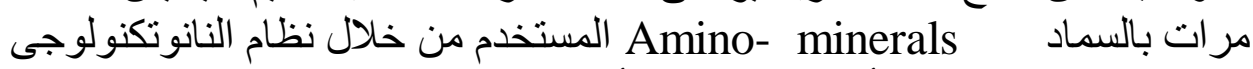
بتركيز 0.1\% من حيث أعلى محصول و أفضل جودة وتلوين الحبات. 
